\title{
Kondisi dan Keragaman Karang Hias di Perairan Pulau Sarang dan Sekitarnya, Kecamatan Belakang Padang, Kota Batam
}

\author{
The Condition and Diversity of Ornamental Corals at Sarang Island Waters and \\ Surrounding, District of Belakang Padang, Batam
}

\author{
Ramses \\ Program Studi Pendidikan Biologi Universitas Riau Kepulauan \\ Korespendensi: ramses.firdaus@gmail.com
}

\begin{abstract}
Abstrak
Kota Batam merupakan wilayah administratif berupa kepulauan yang memiliki keanekaragam jenis karang yang dapat menjadi daya tarik tersendiri. Kondisi biodiversity karang di perairan Batam, khususnya pulau Sarang dan sekitarnya, sudah mengalami degradasi yang parah. Salah satu factor benyebabnya adalah adanya kegiatan pengambilan karang alam secara illegal dan tidak terkontrol untuk memenuhi tingginya permintaan dari Singapura terhadap komoditi karang hias. Penelitian ini bertujuan untuk mengetahui kondisi dan keragaman jenis karang pada perairan Pulau Sarang dan sekitarnya. Pada penelitian ini ditemukan 102 spesies karang keras, dan 15 spesies karang lunak. Persentase tutupan karang hidup rata-rata adalah sebesar 12,78, dengan 95\% Confidence Interval (CI) untuk nilai X (12.78) adalah antara 9.385 dan 16.17\%. Pengambilan karang alam untuk perdagangan ilegal (smaglers) telah berlangsung lama dan sangat massive. Beberapa jenis karang diantarnya Goniopora stutchbury, Goniopora pandoraensis, (nama dagang: Jawstone coral) Discosoma spp, Ricordia spp, Rhodactis spp (False coral/Disk anemons) telah mengalami kepunahan local. Sementara Tubastrea faulkneri (Sanggora coral) sangat sulit ditemukan dan terancam punah secara local. Pembudidayaan karang oleh masyarakat (bukan korporasi) sangat perlu dikembangkan, agar kegiatan budidaya dan perdagangan karang tidak semata-mata dilakukan dengan pendekatan bisnis, agar kelestarian karang dapat terjaga, serta dapat menjamin pemanfaatan yang ramah lingkungan.
\end{abstract}

Kata kunci: Karang hias, keanekaragaman, perdagangan

\begin{abstract}
Batam is an administrative area of the archipelago that has a variety of coral species that can be a special attraction. The condition of coral biodiversity in the waters of Batam, especially the island of Sarang and surrounding areas, has experienced severe degradation. One of the factors is the existence of illegal and uncontrolled natural-harvesting activities to meet the high demand from Singapore for ornamental coral commodities. This study aims to determine the condition and diversity of coral species in the waters of the island of Sarang and surrounding areas. In this study found 102 species of hard coral and 15 species of soft corals. The mean live coral cover percentage was 12.78, with 95\% Confidence Interval (CI) for X value (12.78) being between 9.385 and $16.17 \%$. Natural coral collection for illegal trade (smuggle) has been long and very massive. Several types of corals include Goniopora stutchbury, Goniopora pandoraensis, (trade name: Jawstone coral) Discosoma spp, Ricordia spp, Rhodactis spp (False coral / Disk anemones) have experienced local extinction. While Tubastrea faulkneri (Sanggora coral) is very difficult to find and threatened extinct locally. Coral cultivation by the community (not corporations) needs to be developed so that the coral reef cultivation and trading are not solely done by the business approach, so that the conservation of coral can be maintained, and can guarantee the use of environmentally friendly.
\end{abstract}

Keywords : Coral ornamental, diversity, trade 


\section{PENDAHULUAN}

Ekosistem terumbu karang merupakan ekosistem yang sangat kompleks dengan keanekaragaman hayati yang sangat tinggi, mengingat kondisi atau aspek biologis, ekologis dan morfologis yang sangat khas, maka merupakan suatu ekosistem yang sangat sensitif terhadap berbagai gangguan baik yang ditimbulkan secara alamiah maupun akibat kegiatan manusia (Dahuri, et al., 2001)

Karang (coral) merupakan komponen utama dari ekosistem terumbu karang. Keindahan karang dari ragam jenis karang keras dengan warna dan bentuk mrfologi koloni yang mempunyai estetika yang tinggi, telah banyak dimanfaatkan sebagai penghias aquarium (ornamental corals) (Giyanto, 2007; Rani dan Awaluddinnoer, 2010). Secara umum, walaupun perdagangan karang hias untuk aquarium memiliki volume yang relatif kecil, tetapi memiliki nilai yang sangat tinggi. Berdasarkan CITES (the Convention on International Trade in Endangered Species of Wild Fauna and Flora), karang masuk ke dalam daftar Appendix II yang artinya walaupun dalam perdagangan internasionalnya adalah legal, namun perdagangannya harus dikontrol secara ketat untuk mencegah kemungkinan terjadinya eksploitasi berlebihan yang dapat mengakibatkan punahnya jenis-jenis karang tersebut (Giyanto, 2007).

Kota Batam merupakan wilayah administratif berupa kepulauan yang memiliki keanekaragam jenis karang yang dapat menjadi daya tarik tersendiri. Bahkan telah dilakukan pembudidayaan karang oleh kelompok masyarakat khususnya di Pulau Sarang, Kelurahan Sekanak Raya, Kecamatan Belakang Padang. Kegiatan budidaya karang ini berawal dari kekawatiran terhadap kondisi biodiversity karang di perairan pulau Sarang dan sekitarnya, sudah mengalami degradasi yang parah. Salah satu faktor benyebabnya adalah adanya kegiatan pengambilan karang dari alam secara illegal dan tidak terkontrol untuk memenuhi tingginya permintaan dari Singapura terhadap komoditi karang hias. Letak geografis yang strategis berada dipintu gerbang pusat perdagangan Asia Tenggara telah mempermudah kegiatan penyeludupan sumber daya kelautan dan perikanan. Hal ini telah mendorong masyarakat melakukan eksploitasi dengan tidak bertangung jawab (destructive fishing) dan berdampak pada kerusakan ekosistim terumbu karang secara luas, yang pada akhirnya menyebabkan kepunahan spesies karang tertentu dan hilangnya fungsi ekologis ekosistem terumbu karang. 
Atas dasar kondisi tersebut, penelitian ini dilakukan untuk mengetahui kondisi dan keragaman jenis karang pada perairan Pulau Sarang dan sekitarnya. Inventarisasi keragaman karang merupakan proses untuk mengenali berbagai ragam jenis terumbu karang secara baik. Menurut Johan (2003) pengenalan karang dilakukan secara bertahap, yaitu dari pengenalan bentuk-bentuk pertumbuhan karang (coral life form) dan tipe-tipe koralit terlebih dahulu, kemudian memasuki tingkat marga, dan terakhir ke tingkat spesies. Identifikasi karang hingga ke tingkat spesies sangat sulit dilakukan, karena melibatkan analisa ciri taksonomi yang rumit dan seringkali ciri tersebut tidak kasat mata, bahkan pada beberapa kasus harus menggunakan teknik analisa DNA.

\section{METODE PENELITIAN}

Pengambilan data lapangan dilaksanakan pada tahun 2015-2016 di perairan Pulau Sarang dan sekitarnya. Survey dilakukan pada 9 (sembilan) titik pengamatan yaitu: 1 . Terumbu Resui, 2. Terumbu Layang, 3. Terumbu Malang, 4. Terumbu Tengah, 5. Terumbu Beranak, 6. Terumbu Keling, 7. Terumbu Lumut, 8. Terumbu Anak Lumut, dan 9. Terumbu Pal (Gambar 1). Penanganan dan pengamatan sampel koloni karang untuk keperluan melihat struktur kerangka kapur dilakukan di Laboratorium Ekologi dan Hewan Universitas Riau Kepulauan.

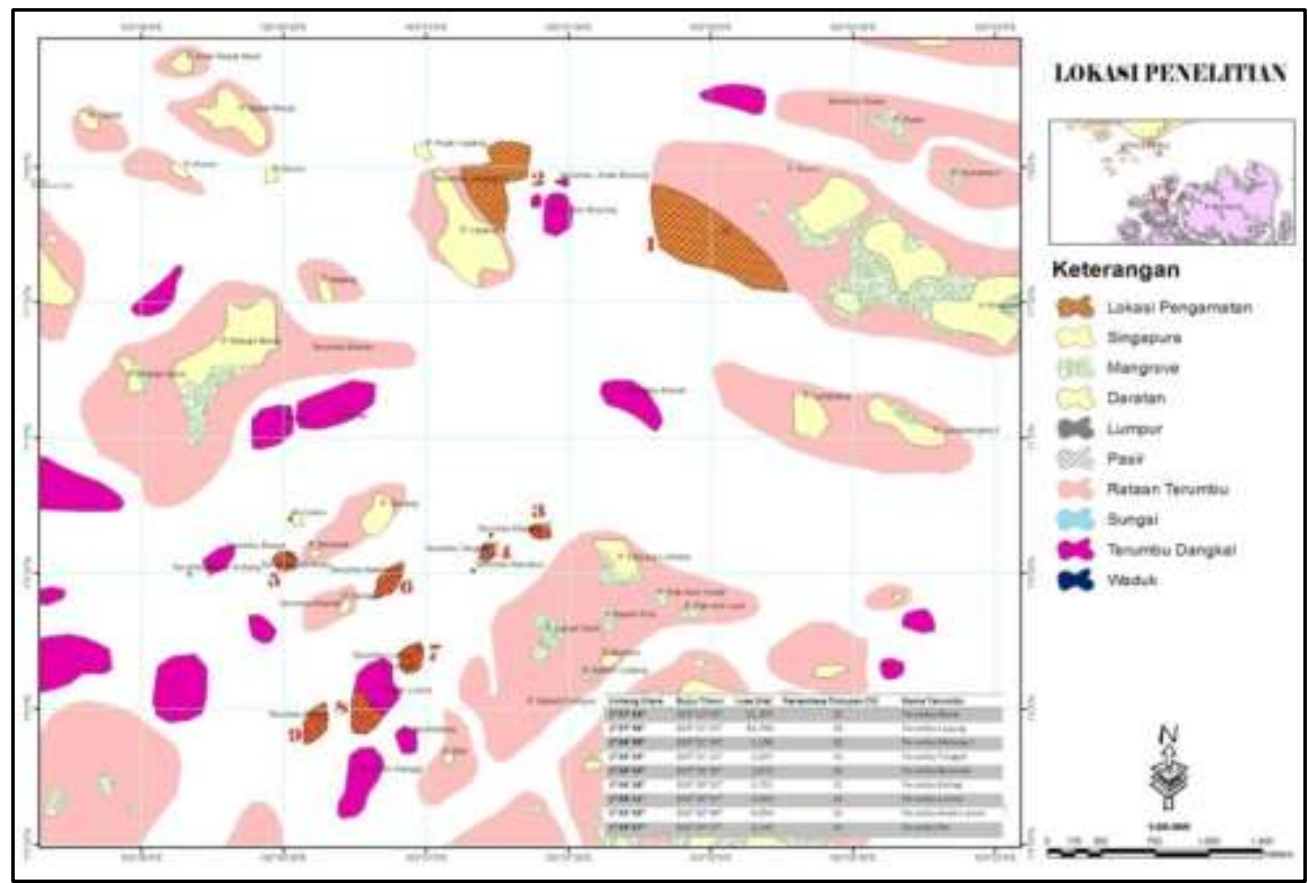

Gambar 1. Lokasi Penelitian 
Metode yang digunakan pada penelitian ini adalah Metode Repid Reef Resources Inventory (RRI) yaitu penilaian secara cepat dan bebas dengan menggunakan peralatan SCUBA terhadap kondisi sumberdaya terumbu karang dan menginventarisasi keragaman jenis karang. Menurut Manuputty et al., (2006) metode RRI digunakan untuk mengetahui persentase tutupan karang hidup, karang mati, jumlah individu maupun jenis biota ikan dan non ikan serta kondisi habitat seperti pasir, pecahan karang, alga, lamun, dan lainnya. Teknik ini dinilai dapat untuk mengestimasi persentase masing-masing kategori bentik dan habitat dalam waktu yang telatif singkat.

Rata-rata persentasi tutupan karang hidup dan 95\% Confidence Interval (CI) pada $\alpha=0025$ ditentukan dengan formula menurut Manuputty et al., (2006) berikut:

$$
\begin{aligned}
& \text { Rerata }=\bar{X}=\frac{\sum_{\text {SII }}^{n} X_{i}}{n} \\
& S D=\sqrt{\frac{\sum_{i s+1}^{n}\left(X_{-}-\bar{X}\right)}{(n-1)}} \\
& \mathrm{SE}=\frac{S D}{\sqrt{n}}
\end{aligned}
$$

95\% $\mathrm{CI}=X \pm($ t tabel $\alpha / 2=0025) . S E$

derajat bebas $(\mathrm{n}-1)$

Luas area pengamatan ditentukan dengan cara melakukan traking GPS dengan mengunakan perahu motor pada area yang diamati dan setiap lokasi dicatat koordinatnya. Untuk keperluan identifikasi dilakukan pemotretan terhadap masing-masing jenis karang dengan mengunakan kamera bawah air (underwater camera). Untuk melihat struktur kerangka kapur, diambil sampel koloni karang dengan ukuran minimal $12 \mathrm{~cm}$ dari berbagai jenis karang yang berbeda. Untuk melengkapi informasi lingkungan perairan juga diambil data parameter kualitas air, terbatas pada Suhu, DO, Salinitas, Kecerahan, dan $\mathrm{pH}$ perairan

Analisa data dan identidikasi karang dikalukan dengan mengamati karakteristik masing-masing spesies yang merujuk pada kunci identifikasi Veron (2000); dan analisa gambar merujuk pada Axelrod (1997); Suharsono, (2008) sebagai rujukan utama. Selanjutnya pada karang keras dilakukan tenik analisa struktur kerangka kapur pada sampel karang yang sudah dikeringkan (dijemur) dan dibersikan. Pengamatan terhadap stuktur kerangka kapur masing-masing sampel karang dilakukan dengan merujuk pada Kelley (2016); Johan, (2003). Bagian-bagian dari rangka kapur karang yang diamati antara lain ialah bentuk koloni, bentuk 
koralit, dan bagian-bagian koralit seperti septa, pali, columella dan coenostium. Alat bantu yang diperlukan untuk analisa ini adalah kaca pembesar.

\section{HASIL DAN PEMBAHASAN}

\section{Parameter Lingkungan}

Parameter lingkungan merupakan foktor penting bagi kelangsungan hidup organisme karang. Pada penelitian ini, kualitas perairan yang diukur terbatas pada suhu, oksigen terlarut, salinitas dan kecerahan. Keempat parameter ini merupakan faktor penting bagi pertumbuhan karang. Hasil pengukuran paramenter perairan diketahui suhu berkisar antara $29-31^{\circ} \mathrm{C}$, DO 6,2-6,6 mg/l, salititas 30-32\%o, dan kecerahan 5-6m (Tabel 1). Kualitas perairan ini masih dalam rentang yang diperbolehkan sesuai dengan baku mutu. Baku Mutu air laut untuk biota laut menurut Keputusan Menteri Negara Lingkungan Hidup Nomor: 51 Tahun 2004 bahwa suhu dan salinitas dinyatakan alami. Dimana nilai suhu dan salinitas perairan dalam kondisi normal suatu lingkungan, bervariasi setiap saat (siang, malam dan musim). Nilai DO dan kecrahan sesuai baku mutu adalah DO $>5 \mathrm{mg} / \mathrm{l}$, dan kecerahan untuk karang $>5 \mathrm{~m}$.

Tabel 1. Hasil pengukuran parameter kualitas perairan di masing-masing lokasi pengamatan

\begin{tabular}{|c|c|c|c|c|c|c|c|c|c|c|c|c|}
\hline \multirow{2}{*}{ Parameter } & \multirow{2}{*}{ Alat } & \multirow{2}{*}{ Satuan } & \multicolumn{9}{|c|}{ Stasiun } & \multirow{2}{*}{$\begin{array}{l}\text { Rata } \\
\text {-rata }\end{array}$} \\
\hline & & & 1 & 2 & 3 & 4 & 5 & 6 & 7 & 8 & 9 & \\
\hline Suhu & Termometer & ${ }^{\circ} \mathrm{C}$ & 30 & 31 & 30 & 29 & 31 & 31 & 29 & 30 & 30 & 30 \\
\hline DO & DO Meter & $\mathrm{mg} / \mathrm{L}$ & 6.4 & 6.5 & 6.6 & 6.5 & 6.4 & 6.2 & 6.2 & 6.4 & 6.4 & 6 \\
\hline Salinitas & Refraktometer & $\%$ & 32 & 30 & 30 & 32 & 31 & 31 & 32 & 32 & 32 & 31 \\
\hline Kecerahan & Secci disk & $\mathrm{m}$ & 6 & 6 & 5 & 5.5 & 6 & 6 & 5 & 6 & 6 & 6 \\
\hline
\end{tabular}

1. Terumbu Resui, 2. Terumbu Layang, 3. Terumbu Malang, 4. Terumbu Tengah, 5.Terumbu Beranak, 6. Terumbu Keling, 7. Terumbu Lumut, 8. Terumbu Anak Lumut, dan 9. Terumbu Pal

Parameter lingkungan perairan untuk terumbu karang yang diukur pada penelitian ini tidak jauh berbeda dengan yang dilaporkan sebelumnya. Sadarun, et.al., (2006), melaporkan bahwa suhu mempengaruhi kecepatan metabolisme dan reproduksi karang. Suhu paling optimal bagi pertumbuhan karang berkisar antara $23-30^{\circ} \mathrm{C}$, semakin tinggi suhu maka semakin tinggi pula metabolisme hewan karang sehingga kelarutan oksigen akan berkurang. Suhu perairan berkisar $29^{\circ} \mathrm{C}$ sampai $30^{\circ} \mathrm{C}$ dapat mendukung pertumbuhan dan kehidupan karang (Mustaqim, Ruswahyuni dan Suryanti, 2013). Salinitas merupakan salah satu faktor pembatas yang sangat penting bagi karang. Kisaran salinitas pada umumnya karang masih ditemukan antara 27\%o sampai 40\%o, dan pertumbuhan terbaik karang berkisar antara 34\%o sampai 36\% (Thamrin, 2006). Nybakken, (1992) menyatakan bahwa terumbu karang sangat 
sensitif terhadap perubahan salinitas yang lebih tinggi atau lebih rendah dari salinitas normal 30-35\%o. Sementara Mustaqim, Ruswahyuni dan Suryanti, (2013) mendapatkan nilai salinitas 32 sampai 34\%o dengan tingkat tutupan karang hidup mencapai 45,51\% hingga 46,2\%.

Kecerahan dan cahaya merupakan dua faktor yang tidak dapat dipisahkan dari karang. Kedua faktor ini menjadi faktor pembatas melalui hubungan secara tidak langsung dengan hewan karang sebagai inang bagi zooxanthellae. Menurut Nybakken (1992) cahaya matahari berperan penting dalam proses pembentukan terumbu karang karena cahaya matahari menentukan kelangsungan proses fotosintesis bagi alga yang bersimbiosis di dalam jaringan karang. Tanpa cahaya yang cukup, laju fotosintesis akan berkurang dan bersama dengan itu kemampuan karang untuk menghasilkan kalsium karbonat dan membentuk terumbu akan berkurang pula.

\section{Kondisi dan Keragaman Karang}

Dari hasil pengamatan pada masing-masing stasiun, diketahui persentase tutupan karang hidup di perairan Pulau Sarang dan sekitarnya sangat rendah yaitu sebesar 10\% hingga $20 \%$ dengan rata-rata sebesar $12,78 \%$ dari 62,447 luas area pengamatan (Tabel 2.). Pada semua lokasi pengamatan ekosistem terumbu karang telah mengalami kerusakan yang berat.

Tabel 2. Persentase tutupan karang hidup dan luas area pengematan

\begin{tabular}{|c|c|c|c|c|c|}
\hline No & Nama Terumbu/ Stasiun & $\begin{array}{c}\text { Lintang } \\
\text { Utara }\end{array}$ & Bujur Timur & $\begin{array}{l}\text { Tutupan Karang } \\
\text { Hidup }(\%)\end{array}$ & Luas $(\mathrm{Ha})$ \\
\hline 1 & Terumbu Resui & $1^{0} 07^{\prime} 44^{\prime \prime}$ & $103^{0} 52^{\prime} 02^{\prime \prime}$ & 20 & 31.297 \\
\hline 2 & Terumbu Layang & $1^{0} 07^{\prime} 56^{\prime \prime}$ & $103^{0} 51^{\prime} 15^{\prime \prime}$ & 10 & 14.744 \\
\hline 3 & Terumbu Malang & $1^{0} 06^{\prime} 39^{\prime \prime}$ & $103^{0} 51^{\prime} 24^{\prime \prime}$ & 10 & 1.196 \\
\hline 4 & Terumbu Tengah & $1^{0} 06^{\prime} 35^{\prime \prime}$ & $103^{0} 51^{\prime} 13^{\prime \prime}$ & 10 & 1.027 \\
\hline 5 & Terumbu Beranak & $1^{0} 06^{\prime} 33^{\prime \prime}$ & $103^{0} 50^{\prime} 30^{\prime \prime}$ & 20 & 1.672 \\
\hline 6 & Terumbu Keling & $1^{0} 06^{\prime} 28^{\prime \prime}$ & $103^{0} 50^{\prime} 52^{\prime \prime}$ & 15 & 2.751 \\
\hline 7 & Terumbu Lumut & $1^{0} 06^{\prime} 11^{\prime \prime}$ & $103^{0} 50^{\prime} 57^{\prime \prime}$ & 10 & 2.563 \\
\hline 8 & Terumbu Anak Lumut & $1^{0} 05^{\prime} 59^{\prime \prime}$ & $103^{0} 50^{\prime} 48^{\prime \prime}$ & 10 & 4.054 \\
\hline 9 & Terumbu Pal & $1^{0} 05^{\prime} 57^{\prime \prime}$ & $103^{0} 50^{\prime} 37^{\prime \prime}$ & 10 & 3.143 \\
\hline \multicolumn{4}{|c|}{$\begin{array}{l}\text { Rata-rata }(\mathrm{X}) \text { persentase tutupan karang hidup dan total luas } \\
\text { area pengamatan }(\mathrm{Ha})\end{array}$} & 12.78 & 62.447 \\
\hline
\end{tabular}

Kerusakan ekosistem terumbu karang ini diduga kuat disebabkan oleh adanya kegiatan mengambilan karang alam dan ikan karang untuk diberdagangkan secara illegal. Selain hal tersebut, ditemukan banyaknya pertikel endapan yang menutupi karang yang mengindikasikan tingginya sedimentasi di kawasan ini. Sedimentasi diduga karena kegiatan 
antropogenik berupa reklamasi dan alur trasportasi kapal domestik. Dari hasil analisa data di peroleh nilai rata-rata $(\mathrm{X})$ persentase tutupan karang sebesar 12,78, dengan 95\% Confidence Interval (CI) untuk nilai X rata-rata (12.78) adalah antara 9.385 dan $16.17 \%$ (dimana Standev $(\mathrm{SD})=4.409, \mathrm{SE}=1.469$ pada $\left.\mathrm{t}_{\text {tabel }} \alpha=0.025=2,306\right)$. Dari hasil survey, ditemukan 102 spesies karang keras, dan 15 spesies karang lunak (Tabel 3.).

Tabel 3. Jenis Karang Keras dan Lunak yang di Periran Pulau Sarang dan Sekitarnya

\begin{tabular}{|c|c|c|c|}
\hline \multicolumn{4}{|c|}{ A. Karang Keras (Hard Coral) } \\
\hline Acropora milepora & Acropora robusta & Acropora tenuis & Acropora donei \\
\hline Acropora palifera & Acropora humilis & Acropora sarmentosa & Acropora striata \\
\hline Euphylia ancora & Euphyllia paraancora & Plerogyra sinuosa & Plerogyra spl \\
\hline Symphyllia recta & Symphyllia agaricia & Physogyra lichtensteini & Physogyra spl \\
\hline Cycloseris patelliformis & Fungia fralinae & Cycloseris patelliformis & Ctenactis echinata \\
\hline Stylophora spl & Pachyseris rugosa & Pachyseris speciosa & Psammocora spl \\
\hline Montipora tuberculosa & Palauastrea ramosa & Montipora foliosa & Turbinaria peltata \\
\hline Montipora spl & Montipora capricornis & Montipora tuberculosa & Oulophyllia crispa \\
\hline Tubinaria bifrons & Turbinaria mesenterina & Turbinaria stellulata & Euphylia divisa \\
\hline Pocillopora damicornis & Palauastrea ramosa & Hydnophora spl & Pachyseris speciosa \\
\hline Leptoseris spl & Podabacia sinai & Merulina ampliata & Acanthastrea echinata \\
\hline Alveopora spongiosa & Wellsophyllia radiata & Leptoseris papyracea & $\begin{array}{l}\text { Symphyllia } \\
\text { valenciennesi }\end{array}$ \\
\hline Symphyllia agaricia & Symphyllia agaricia & Symphyllia valenciennesi & Symphyllia sp4 \\
\hline Symphyllia sp5 & Symphyllia spl & Symphyllia sp2 & Symphyllia sp3 \\
\hline Lobophyllia robusta & Mussa angulosa & $\begin{array}{l}\text { Australomussa } \\
\text { rowleyensis }\end{array}$ & Trachyphyllia spl \\
\hline Lobophyllia hataii & Lobophyllia corymbosa & Trachyphyllia sp2 & Trachyphyllia sp3 \\
\hline Lobophyllia sp2 & Lobophyllia flabelliformis & Lobophyllia hemprichii & Lobophyllia spl \\
\hline Pectinia paeonia & Pavona cactus & Seriotopora caliendrum & Pectinia lactuca \\
\hline Goniopora lobata & Pectinia spl & Pectinia sp2 & Pectinia sp2 \\
\hline Caulastrea furcata & Goniopora stutchburyi & Goniopora pandoraensis & Goniopora spl \\
\hline $\begin{array}{l}\text { Montastrea } \\
\text { valenciennesi }\end{array}$ & Pavona decussata & Favia albidus & Favia helianthoides \\
\hline $\begin{array}{l}\text { Montastraea } \\
\text { magnistellata }\end{array}$ & Caulastrea tumida & Acanthastrea hillae & Acanthastrea echinata \\
\hline Galaxea spl & Pseudosiderastrea tayami & Oulophyllia bennettae & Galaxea fascicularis \\
\hline Favia maxima & Goniastrea favulus & Goniastrea aspera & $\begin{array}{l}\text { Goniastrea } \\
\text { australiensis }\end{array}$ \\
\hline Favia abdita & Favia lizardensis & Favia rotundata & Favia speciosa \\
\hline Tubastrea micrantha & Tubastrea faulkneri & - & - \\
\hline \multicolumn{4}{|c|}{ B. Karang lunak (Soft coral) } \\
\hline Cladiella spl & Sphaerella krempfi & $\begin{array}{l}\text { Sarcophyton } \\
\text { trocheliphorum }\end{array}$ & Cladiella sp2 \\
\hline Sphaerella krempfi & Sarcophyton acutangulum & Ricordia yuma & Ricordia spl \\
\hline Ricordia sp2 & Discosoma sp & Actinodiscus spl & Actinodiscus sp2 \\
\hline Rhodactis mushroom & Rhodactis mushroom & Rhodactis mushroom & \\
\hline
\end{tabular}


Keragaman karang yang dijumpai sangat tinggi, namun tutupan karang hidup di setiap stasium pengamatan sangat rendah. Hal ini mengindikasikan kegiatan pengambilan karang alam untuk perdagangan ilegal (smaglers) telah berlangsung lama dan sangat massive. Penelitian ini juga mengkompirmasi beberapa jenis karang diantarnya Goniopora stutchbury, Goniopora pandoraensis (nama dagang: Jawstone coral) Discosoma spp, Ricordia spp, Rhodactis spp (False coral/Disk anemons) telah mengalami kepunahan local. Sementara Tubastrea faulkneri (Sanggora coral) sangat sulit ditemukan (terancam punah).
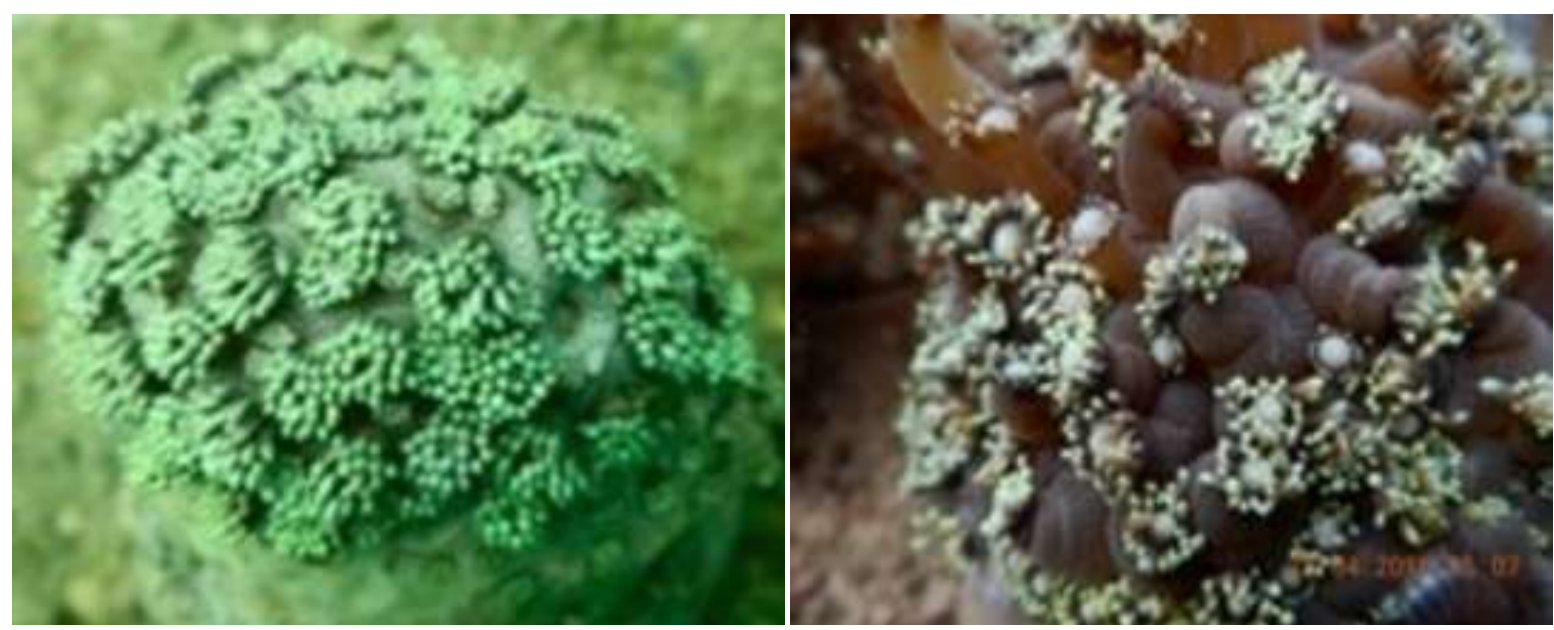

Gambar 2. Jenis Karang Hias Goniopora stutchburyi (kiri) dan Goniopora pandoraensis (kanan)

Kerusakan ekosistem terumbu karang akibat adanya perdagangan karang hias secara illegal ini telah berdampak pada hasil tangkap perikanan, khususnya nelayan bubu sebagai mata pencaharian umum masyarakat di lokasi penelitian. Menurut Haruddin, Purwanto, dan Budiastuti (2011) bahwa kerusakan ekosistem terumbu karang sangat berpengaruh terhadap hasil tangkapan ikan nelayan tradisional di pulau Siompu Kabupaten Buton yang ditandai dengan adanya kecenderungan penurunan hasil tangkapan pada lima tahun terakhir sebesar 4,30 ton $(25,95 \%)$ pada pada tahun 2006 menjadi 2,47 ton $(14,91 \%)$ pada tahun 2010 . Selanjutnya Sjafrie (2010) melaporkan nilai ekonomi terumbu karang di Selat Nasik diperolae dari nilai sebagai bahan bangunan, habitat ikan dan pelindung pantai,

Selain terganggunya hasil tangkap perikanan, kerusakan fisik terhadap struktur terumbu karang meningkatkan kerawanan ekosistem pulau kecil yang memiliki elevasi sangat rendah. Berdasarkan konteks adaptasi dan mitigasi dampak perubahan iklim, sangat penting mempertahankan dan memulihan terumbu karang sebagai ekosistem pelindung, bersinergi dengan padang lamun dan hutan mangrove (Moore, et al., 2015). 
Terumbu karang yang terkena polusi berbasis darat (limbah, sedimentasi, dan / atau polusi industri) menunjukkan 30-50\% mengurangi keragaman pada kedalaman $3 \mathrm{~m}$, dan 40$60 \%$ mengurangi keragaman pada kedalaman 10m dibandingkan dengan terumbu karang yang tidak tercemar. Terumbu yang rusak akibat bom fishing atau jangkar menyebabkan kurangnya $50 \%$ beragam karang pada perairan dangkal (kedalaman $3 \mathrm{~m}$ ) daripada terumbu karang yang tertinggal di wilayah yang sama, namun pada kedalaman $10 \mathrm{~m}$, penurunan keragaman relatif kecil 10\% (Edinger, Jompa, Limmon, Widjatmoko, \& Risk, 1998).

Karang hias sangat potensial dan bernilai ekonomis tinggi. Keberadaan sebagian karang hias di alam dikuatirkan akan habis apabila aktivitas perdagangan terus meningkat dan ditemukan solusi pemecahannya. Stok karang hias yang berasal dari hasil budidaya akan dapat menggurangi pengambilan dari alam, manajemen terbaik untuk menjaga sustainable use sumber daya karang hias ini sangat diperlukan sehingga dapat menjaga biodiversitas karang di masa depan (Johan, 2006). Namun, kegiatan pembudidayaan karang oleh masyarakat (bukan korporasi) sangat perlu dikembangkan, agar kegiatan budidaya dan perdagangan karang yang legal, tidak semata-mata dilakukan dengan pendekatan bisnis seperti yang berjalan saat ini di Indonesia. Dengan demikian kepedulian masyarakat terhadap kelestarian karang dapat terjaga, serta dapat menjamin pemanfaatan yang ramah lingkungan.

\section{KESIMPULAN}

Pada penelitian ini ditemukan 102 spesies karang keras, dan 15 spesies karang lunak. Persentase tutupan karang hidup rata-rata adalah sebesar 12,78, dengan 95\% Confidence Interval (CI) untuk nilai X (12.78) adalah antara 9.385 dan $16.17 \%$. Pengambilan karang alam untuk perdagangan ilegal (smaglers) telah berlangsung lama dan sangat massive. Beberapa jenis karang diantarnya Goniopora stutchbury, Goniopora pandoraensis, (Jawstone Coral) Discosoma spp, Ricordia spp, Rhodactis spp (False coral/Disk anemons) telah mengalami kepunahan local. Sementara Tubastrea faulkneri (Sanggora coral) sangat sulit ditemukan dan terancam punah secara local. Pembudidayaan karang oleh masyarakat (bukan korporasi) sangat perlu dikembangkan, agar kegiatan budidaya dan perdagangan karang tidak sematamata dilakukan dengan pendekatan bisnis, agar kelestarian karang dapat terjaga, serta dapat menjamin pemanfaatan yang ramah lingkungan. 


\section{DAFTAR PUSTAKA}

Dahuri, R, Rais, J., Ginting, S.P. dan Sitepu, M.J. 2001. Pengelolaan Sumberdaya Wilayah Pesisir dan Lautan secara Terpadu. PT. Pradnya Paramita, Jakarta. 326 hal.

Edinger, E. N., Jompa, J., Limmon, G. V., Widjatmoko, W., and Risk, M. J., 1998. Reef Degradation and Coral Biodiversity in Indonesia: Effects of Land-Based Pollution, Destructive Fishing Practices and Changes over Time. Marine Pollution Bulletin 36(8):617-30.

Giyanto 2007. Perdagangan karang hias : Suatu ancaman terhadap ekosistem terumbu karang?. Oseana, Volume XXXII, (4): 21 - 27

Haruddin, Purwanto, dan Budiastuti, S., 2011. Dampak Kerusakan Ekosistem Terumbu Karang Terhadap Hasil Penangkapan Ikan Oleh Nelayan Secara Tradisional di Pulau Siompu Kabupaten Buton Propinsi Sulawesi Tenggara. Jurnal EKOSAINS. 3(3): 29-41

Johan, O., 2003. Training Course: Karakteristik Biologi Karang. PSK-UI dan Yayasan TERANGI, Jakarta.

Johan, O. (2006). Mengenal karang hias bernilai ekonomis penting di Indonesia. Media Akuakultur, 1(3), 87-90. https://doi.org/10.15578/ma.1.3.2006.87-90

Kelley R. (2016). Indo-Pacific Coral Finder 2.0. The Australian Coral reef Society. EYO Guides, Australia.

Manuputty, A. E.W., Giyanto, Winardi, Suharti, S.R., Djuwariah, 2006. Manual Monitoring Kesehatan Karang. Coremap-LIPI, Jakarta. 109 hal.

Mustaqim, M.M., Ruswahyuni dan Suryanti, 2013. Kelimpahan jenis Bulu Babi (Echinoidea, leske 1778) di rataan dan tubir terumbu karang di perairan si Jago - Jago, Tapanuli Tengah. Maquares, Volume 2(4): 61-70

Moore, A., Ndobe, S., Salanggon, Al.I.M. dan Wahyud, D., 2015. Ekosistem Terumbu Karang di Pulau Sonit, Kepulauan Banggai: Biodiversitas dan Isu-Isu Pengelolaan. Prosiding Simposium Nasional Kelautan dan Perikanan II. Universitas Hasanuddin, Makassar.

Nybakken, J. W., 1992. Biologi Laut Suatu Pendekatan Ekologis. PT. Gramedia. Jakarta

Rani, C. dan Awaluddinnoer, 2010. Sintasan dan laju pertumbuhan fragmen karang Acropora loripes antara induk hasil transplantasi (F1) dan induk dari alam (F0). Seminar Nasional Tahunan VII Hasil Penelitian Perikanan dan Kelautan. Universitas Gajah Mada. PK05, hal 1-7

Sadarun, B., Nezon, E., Wardono, S., Afandy, Y.A., Nuriadi, L. 2006. Petunjuk Pelaksanaan Transplantasi Karang. Departemen Kelautan dan Perikanan. Jakarta 36 hal

Sjafrie, N. D. M. (2010). Nilai Ekonomi Terumbu Karang Di Kecamatan Selat Nasik, Kabupaten Belitung. Oseanologi Dan Limnologi Di Indonesia, 36(1), 97-109.

Suharsono. 2008. Jenis-Jenis Karang di Indonesia. LIPI Press. Jakarta

Suryanti, Supriharyono dan Y. Roslinawati. 2011. Pengaruh Kedalaman Terhadap Morfologi Karang di Pulau Cemara Kecil, Taman Nasional Karimunjawa. Jurnal Saintek Perikanan. 7 (1): $63-69$

Thamrin. 2006. Karang (Biologi Reproduksi dan Ekologi). Penerbit Minamandiri, Pekanbaru.

Veron J.E.N., eds., 2000, Corals of the World, Australian Institute of Marine Science, Townsville, pp.1382 